\title{
The effect of estrogen on craniofacial dimensions: a systematic review
}

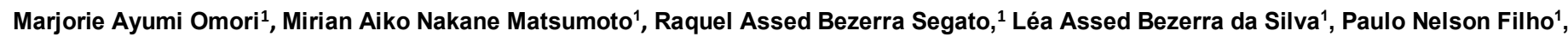
Erika Calvano Kuchler ${ }^{1}$

${ }^{1}$ Department of Pediatric Dentistry, School of Dentistry of Ribeirão Preto (University of São Paulo), Ribeirão Preto/SP Brazil

\section{Abstract}

Sex hormones have an effect on bone metabolism. However, it remains unclear how estrogen hormone affects mandible and maxilla growth and development. The aim of this study was to perform a systematic review to evaluate if estrogen is associated with developmental alterations in the maxilla/mandible phenotype. Material and methods: A computer search of the literature was performed using: Pubmed Medline (1966 - August 2018), Google Scholar and manual searching. A combination of the terms 'estrogens', 'mandible', 'dental arch', 'maxilla', 'craniofacial', 'growth' and 'development' was used. Studies that used animal models to evaluate the role of estrogen during growth and development on the dimensions of the maxilla and/or mandible were included. Results: 5 studies were selected to compose this systematic review. One study used zebrafish as a model. Two studies used female mice and 2 studies used female rats as a model. Two studies treated the animals with estrogen. Four studies demonstrated that estrogen has an effect on mandible dimension and 2 studies demonstrated that estrogen has an effect on maxilla. One study did find an association between estrogen deficiency and mandible/maxilla dimensions Conclusion: The current evidence suggested that both, increased and decreased levels of estrogen, have an effect on the maxilla and mandible dimensions.

\section{Introduction}

The understanding of craniofacial growth has been investigated in orthodontic field (1-3). Studies have demonstrated that the properly growth and development of the maxilla and mandible requires the coordination of a variety of molecular mechanisms (4-6). In fact, bone growth and development is mediated by different factors, such as hormones and sex hormones. It is well known that sex hormones are important in the regulation of reproductive functions and play an important in bone growth and maintenance (7).

Estrogen is a sex hormone, mainly produced by ovaries, which has a multifunctional role in growth, development, differentiation and function of various tissues. The role of estrogen in the bone development begins in the embrionary period (8) until the puberty (9). Different studies with animal models have suggested that estrogen has an important role on the maxillary arches (9-12). Therefore, the aim of this study is to perform a systematic review to evaluate the effect of estrogen and/or Estrogen receptors on the maxilla and mandible growth.

\section{Material and Methods}

Focused questions, protocol and Data search
Citation: Omori M, et al. (2019) The effect of estrogen on craniofacial dimensions: a systematic review. Dentistry 3000. 1:a001 doi:10.5195/d3000.2019.84 Received: August 7, 2018

Accepted: September 18, 2018

Published: June 26, 2019

Copyright: C2019 Omori M, et al. This is an open access article licensed under a Creative Commons Attribution Work 4.0 United States License.

Email:erikacalvano@gmail.com
The present systematic review was conducted in order to answer two focused questions: I) Does estrogen levels affect maxilla and mandible growth?

II) Does Estrogen receptors (ERs) affect maxilla and mandible growth?

To conduct this review, the PRISMA STATEMENT (Figure 1) checklist was used.

Initially a broad survey was conducted on computer of the literature by using the Pubmed Medline (1966- Aug 2018), Google Scholar (1960- Aug 2018) and manual search databases.

Review process 
The initial selection of the studies was done through the title and abstract. The full text analyses of the potentially relevant studies were made. Two examiners selected the studies. When there was some sort of disagreement, a third examiner was requested.

\section{Terms}

The search strategy was based on the following Medical Subject Heading terms (MeSH) or Text Word [tw] in different combination strategy. The following terms were used: "Estrogens" AND “Mandible OR maxilla OR dental arch OR craniofacial" AND "Growth OR development". Data was extracted and pooled in a table, to facilitate the visualization of information.

\section{Inclusion and Exclusion Criteria}

Studies that used animal models to assess the effect of estrogen during maxilla and mandible growth and have maxilla and mandible dimensions as an outcome were included.

There was no language or date restriction.

In vitro studies, clinical studies, case reports, case series and review have been excluded, as well as patents and conferences were excluded.

\section{Data extraction}

Two authors extracted the relevant data from the included papers. From each included study, the description of the animal models used, experimental design, dimensions results and additional information were summarized in tables 1 and 2 .

\section{Results}

The electronic search of PubMed and Google Scholar yielded 1.120 citations. A total of 31 titles and abstracts were screened from the selected databases. There were 15 in PubMed, and 16 in google scholar. The duplicates were considered only once, totalizing just 1 paper. Additionally, 1 more paper was selected by manual searching. Initially, the titles and abstracts not connected with the topic were excluded. Afterwards, the papers were selected according to the inclusion and exclusion criteria, then 13 papers were selected for full text analysis.

After reading, 8 papers were excluded. Thus, 5 full texts were included for this systematic review.

Table 1. Characteristics of the included studies

\begin{tabular}{|c|c|c|c|c|c|}
\hline Author/year & Animal model & Treatment & Sample size & $\begin{array}{c}\text { Age of } \\
\text { treatment }\end{array}$ & $\begin{array}{c}\text { Craniofacial measurement } \\
\text { method }\end{array}$ \\
\hline $\begin{array}{c}\text { Singh IJ and Gunberg } \\
\text { DL. (1971) }\end{array}$ & Female rats & $\begin{array}{l}\text { Treated with E2; } \\
\text { Received } 0.2 \text { ug of } 17- \\
\text { Beta-Estradiol daily for } 30 \\
\text { days. }\end{array}$ & $\begin{array}{l}20 \text { experimental } \\
20 \text { controls }\end{array}$ & 30 days old & $\begin{array}{l}\text { Gross bone measurements } \\
\text { Linear measurements } \\
\text { (Mandible) }\end{array}$ \\
\hline Fujita T. et al. (2004) & Female mice & Ovariectomy (OVX) & $\begin{array}{l}10 \text { experimental } \\
10 \text { control }\end{array}$ & 5 days old & $\begin{array}{l}\text { Lateral cephalograms (X-ray) - } \\
\text { Cephalometric analysis } \\
\text { Linear measurements } \\
\text { (Maxilla and mandible) }\end{array}$ \\
\hline $\begin{array}{l}\text { Masoud S. et al. } \\
\qquad(2008)\end{array}$ & Wistar rats & Ovariectomy (OVX) & $\begin{array}{l}-15 \text { experimental } \\
-10 \text { control }\end{array}$ & 30 days old & $\begin{array}{l}\text { Direct milimetric measurements } \\
\text { (Electronic Caliper) } \\
\text { (Maxilla and mandible) }\end{array}$ \\
\hline $\begin{array}{l}\text { Fushimi S. et al. } \\
\qquad(2009)\end{array}$ & Zebrafish & $\begin{array}{l}\text { Treated with various } \\
\text { concentrations of E2. }\end{array}$ & $\begin{array}{l}\text { Embryos experimental } \\
\text { Embryos control }\end{array}$ & - & $\begin{array}{l}\text { Gross morphology (assessed by } \\
\text { Microscope) } \\
\text { Analysis of morphological changes } \\
\text { (Upper and lower jaw) }\end{array}$ \\
\hline $\begin{array}{l}\text { Márquez Hernández } \\
\text { R.A. et al. (2011) }\end{array}$ & Female mice & $\begin{array}{l}\text { The experimental group } \\
\text { were subjected to daily } \\
\text { subcutaneous injection: } \\
\text {-ER } \alpha \text { antagonists; } \\
\text {-ER } \beta \text { antagonists; }\end{array}$ & $\begin{array}{l}10 \text { ERa (5 Female ; } 5 \\
\text { Male) } \\
10 \text { ER } \beta \text { ( } 5 \text { Female ; } 5 \\
\text { Male) }\end{array}$ & 5 days old & $\begin{array}{l}\text { Lateral cephalograms (X-ray) - } \\
\text { Cephalometric analysis } \\
\text { Linear measurements } \\
\text { (Mandible) }\end{array}$ \\
\hline
\end{tabular}


The summary of the characteristics of the 5 included papers is described in the table 1.

The authors followed different protocols to evaluate the effect of estrogen levels or ERs in the maxilla and mandible growth. Only one study used zebrafish as animal model (13). The others 4 studies used mammals, 2 female rats (10, $11)$ and 2 female mice $(9,12)$. Two studies ovarectomized the experimental group in order to induce estrogen deficiency $(9,11)$. Others two studies treated with Estradiol (E2) to induce an increase of estrogen $(10,13)$, and only one study treated the animals with Estrogen Receptors (alfa and beta) antagonists (12).

The author who treated the animals with E2 (10) found an increase in mandibular measurements: CondylionPogonion (Co-Pog) and CondylionGonion (Co-Go).

Fujita et al. (9) induced estrogen deficiency and found some smaller linear distances in the maxilla: Mu$\operatorname{Pr}$ (Mu: Point on intersection between maxillary bone and mesial surface of upper first molar; Pr: Most inferior and anterior point on alveolar process of premaxilla), A-Pr (A: Most anterior point on nasal bone; Pr:
lu-Bu (lu: Most prominent point between incisal edges of upper incisors; Bu: Point on premaxilla between jawbone and lingual surface of upper incisors). In the mandible, the distances Pg-Gn (Pg: Point on most inferior contour of lower border of mandible, adjacent to incisors; Gn: Point on most inferior contour of angular process of mandible), $\mathrm{Ml}-\mathrm{Bl}$ ( $\mathrm{Ml}$ : Point on intersection between the mandibular alveolar bone and mesial surface of first molar; Bl: Point on intersection between lingual surface of lower incisor and anteriormost part of lingual alveolar bone), Co-Co' (Co: Most posterosuperior point of condylar

\begin{tabular}{|c|c|c|c|c|}
\hline Author/year & $\begin{array}{l}\text { Effect on } \\
\text { Maxilla }\end{array}$ & Effect on Mandible & Author's conclusion & Additional information \\
\hline $\begin{array}{l}\text { Singh IJ and } \\
\text { Gunberg DL. } \\
\quad(1971)\end{array}$ & Not reported & $\begin{array}{l}\text { There was an } \\
\text { increase the Go-Pog } \\
\text { and Co-Go } \\
\text { dimensions. }\end{array}$ & $\begin{array}{l}\text { The inhibitory effect on linear measurements } \\
\text { was transitory and by the end of the period } \\
\text { bone size was normal. }\end{array}$ & $\begin{array}{l}\text { Differences in the linear dimensions of } \\
\text { Mandible are maximum at age of } 60 \text { days }\end{array}$ \\
\hline $\begin{array}{c}\text { Fujita T. et al. } \\
(2004)\end{array}$ & $\begin{array}{l}\text { The } \\
\text { dimensions } \\
\text { Mu-Pr, A-Pr } \\
\text { and lu-Bu } \\
\text { were smaller }\end{array}$ & $\begin{array}{l}\text { The dimensions Pg- } \\
\text { Gn, Ml-BI, Co-Co' } \\
\text { and II-Id were } \\
\text { significantly smaller. }\end{array}$ & $\begin{array}{l}\text { Suggested that the suppression of sex } \\
\text { hormone secretion in the growth phase } \\
\text { might inhibit craniofacial growth and result } \\
\text { in poor craniofacial development in the } \\
\text { growth phase. }\end{array}$ & $\begin{array}{l}\text { No significant differences in all the } \\
\text { angular measurements of the } \\
\text { neurocranium were found between the } \\
\text { OVX and sham groups }\end{array}$ \\
\hline $\begin{array}{l}\text { Masoud S. et } \\
\text { al. (2008) }\end{array}$ & $\begin{array}{l}\text { No significant } \\
\text { differences }\end{array}$ & $\begin{array}{l}\text { No significant } \\
\text { differences }\end{array}$ & $\begin{array}{l}\text { Suggested that the suppression of } \\
\text { sex hormones secretion in the growth } \\
\text { phase might inhibit craniofacial growth } \\
\text { and results in poor craniofacial } \\
\text { development/ malocclusion developing }\end{array}$ & $\begin{array}{l}\text { Estradiol level did not change in } \\
\text { ovariectomized group. No significant } \\
\text { differences, except weight were found } \\
\text { between the groups. }\end{array}$ \\
\hline $\begin{array}{l}\text { Fushimi S. et } \\
\text { al. (2009) }\end{array}$ & $\begin{array}{l}\text { Deformation of } \\
\text { the upper jaw } \\
\text { plate leading } \\
\text { to a smaller } \\
\text { maxilla. }\end{array}$ & $\begin{array}{l}\text { Hypoplasia of lower } \\
\text { jaw leading to a } \\
\text { smaller mandible. }\end{array}$ & $\begin{array}{l}\text { High concentrations of E2 caused abnormal } \\
\text { cartilage formation, suggesting possible } \\
\text { teratogenic effects of E2 on } \\
\text { chondrogenesis in zebrafish embryos. }\end{array}$ & $\begin{array}{l}\text { At the E2 concentration of } 1.5 \times 10-5 \mathrm{M} \text {, } \\
\text { all embryos displayed severe } \\
\text { morphological abnormalities }\end{array}$ \\
\hline $\begin{array}{l}\text { Márquez } \\
\text { Hernández } \\
\text { R.A. et al. } \\
\text { (2011) }\end{array}$ & Not reported & $\begin{array}{l}\text { Condylar height and } \\
\text { mandibular length } \\
\text { were significantly } \\
\text { smaller in the ER } \beta \\
\text { antagonist injection }\end{array}$ & $\begin{array}{l}\text { Immediately after birth, sex hormone } \\
\text { deficiency reduces the expression of } \\
\text { sex hormone receptors on }\end{array}$ & $\begin{array}{l}\text { Mandibular growth were significantly } \\
\text { affected in the group injected with ER } \beta \\
\text { antagonist }\end{array}$ \\
\hline
\end{tabular}

Most inferior and anterior point on alveolar process of premaxilla), 
Co) and II-Id (II: Most prominent point between incisal edges of lower incisor; Id: Most inferior and anterior point on alveolar process of mandible) were significantly smaller. Besides, no significant differences in all angular measurements were found between the ovarectomized and sham-operated groups. The study that treated Zebrafish with different concentrations of E2 detect a deformation of the upper jaw plate, leading to a smaller maxilla and hypoplasia of the lower jaw, leading to a smaller mandible.

Márquez Hernández et al. (12) evaluate the effect of ER $\beta$ antagonist in the mandible and found that condylar height and mandibular length were significantly smaller; the mandibular growth was significantly affected with the injection. Just one author (11) from this systematic review found no significant differences in its study.

\section{Discussion}

Previous studies have already demonstrated that sex hormones can stimulate osteoclast differentiation directly (14) or indirectly (15) and that estrogen has an effect on bone metabolism (16-18). In cases of low levels of estrogen, there is an increase of the osteoclast count and surface; whereas in cases of high levels of estrogen, the opposite occurs: bone formation, bone healing and regeneration $(19,20)$. This hormone express its skeletal effects by its binding to estrogen receptors (ERs) (21).

In the present systematic review, we included studies that used

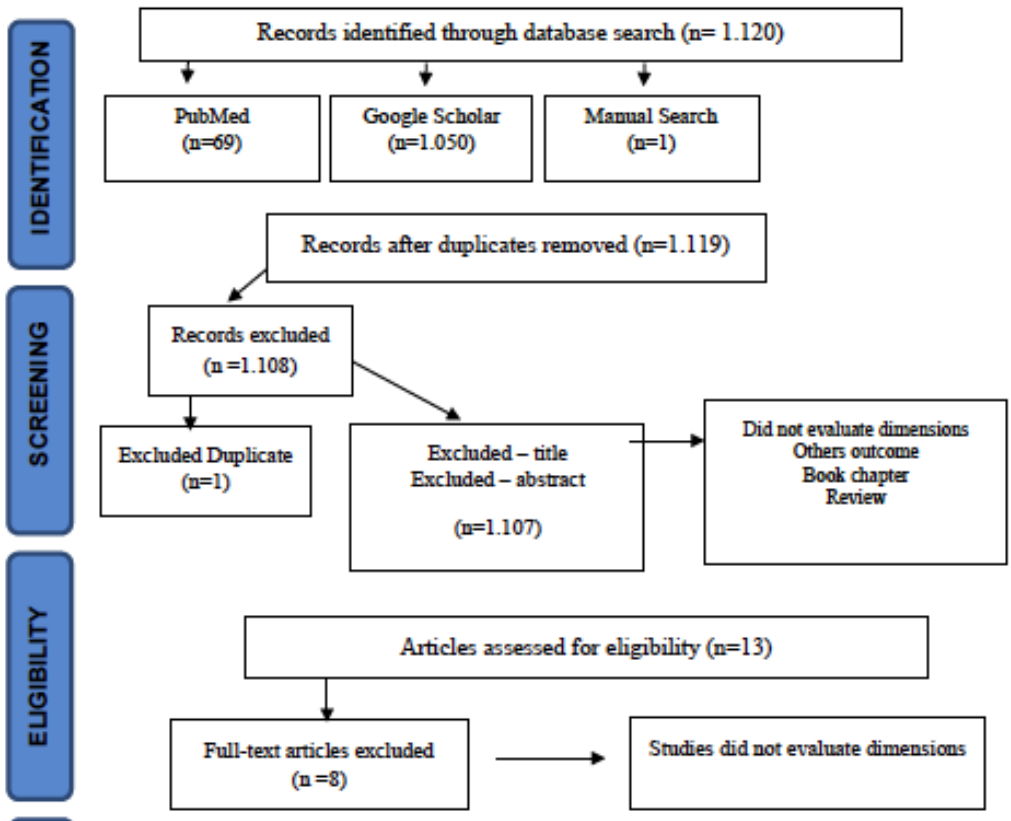

Studies were selected for the systematic review $(n=5)$

mammals as well as zebrafish as animal models. These studies demonstrated the effect of estrogen on the maxilla $(9,12,13)$ and mandible dimensions $(9,10$, $12,13)$. The zebrafish is an important animal model in health and genetic science nowadays due the fact that its genome has been fully sequenced and evidences revealed that $71.4 \%$ of human genes are related to zebrafish genes (22). Only one study observed that an increase of estrogen causes a deformation of the upper and lower jaw leading to a smaller maxilla and mandible, interestingly this study used Zebrafish as animal model (13). This fact could be explained by the physiological differences that exist between mammals and zebrafish. Otherwise, studies that used mice found that a reduction of the craniofacial dimensions occurs when estrogen decreases or when there is a binding in the specific estrogen receptors, blocked through ERs antagonists $(9,12)$. Following the same line, Singh \& Gunberg (10) demonstrated an increase in the linear measurements of the mandible when rats receive estrogen daily. These results clearly suggested that estrogen play an important role in mammals maxilla and mandible development. Studies that use mammals as an animal model allow more reproducibility for human development understanding once over $90 \%$ of human and mouse genomes can be divided into parts with corresponding regions (23) and 
the comparative genomics allow a link between researches using animal model (preclinical researches) and humans (23-25).

It is important to highlight that none of the studies evaluated the role of the estrogen during puberty period. In the orthodontic treatment it is crucial to predict the effective period of treatment to improve the skeletal discrepancy between maxillary and mandibular arches, so it is necessary a development of an indicator of bone maturity (for example a hormonal indicator), that would help to establish the beginning and end of growth (12). Therefore, more studies should focus in the understanding of the role of the estrogen and estrogen receptor during different periods of the craniofacial development.

Briefly, these translational investigations are indispensable to clearly demonstrate the influence of sex hormones, specifically estrogen, on craniofacial bone growth.

\section{Conclusion}

The current evidence suggested that both, increased and decreased levels of estrogen have an effect on the maxilla and mandible dimensions.

\section{Acknowledgments}

Funding sources: Fundação de Amparo à Pesquisa do Estado de São Paulo (FAPESP) 2016/13982-4; 2015/ 06866-5.

\section{References}

1. Choi SH, Fan D, Hwang MS, Lee HK, Hwang CJ. Effect of growth hormone treatment on craniofacial growth in children: Idiopathic short stature versus growth hormone deficiency. J Formos Med Assoc. 2016.

2. da Fontoura CS, Miller SF, Wehby GL, Amendt BA, Holton NE, Southard TE, et al. Candidate Gene Analyses of Skeletal Variation in Malocclusion. J Dent Res. 2015;94(7):913-20.

3. Yoon SS, Chung $\mathrm{CH}$. Comparison of craniofacial growth of untreated Class I and Class II girls from ages 9 to 18 years: a longitudinal study. Am J Orthod Dentofacial Orthop. 2015;147(2):190-6.

4. Sidlauskas $\mathrm{M}$, Salomskiene $L$, Andriuskeviciute I, Sidlauskiene M, Labanauskas Z, Vasiliauskas A, et al. Heritability of mandibular cephalometric variables in twins with completed craniofacial growth. Eur J Orthod. 2016;38(5):493-502.

5. Pallares LF, Carbonetto P, Gopalakrishnan S, Parker CC, Ackert-Bicknell $C L$, Palmer $A A$, et al. Mapping of Craniofacial Traits in Outbred Mice Identifies Major Developmental Genes Involved in Shape Determination. PLoS Genet. 2015;11(11):e1005607.

6. Parada C, Chai Y. Mandible and Tongue Development. Curr Top Dev Biol. 2015;115:31-58.

\section{Lorenzo J. A new}

hypothesis for how sex steroid hormones regulate bone mass. J Clin Invest. 2003;111(11):1641-3.

8. Ben-Hur H, Mor G, Blickstein I, Likhman I, Kohen F, Dgani $R$, et al. Localization of estrogen receptors in long bones and vertebrae of human fetuses. Calcif Tissue Int. 1993;53(2):91-6.

9. Fujita T, Ohtani J, Shigekawa M, Kawata T, Kaku M, Kohno S, et al. Effects of sex hormone disturbances on craniofacial growth in newborn mice. J Dent Res. 2004;83(3):2504.

10. Singh IJ, Gunberg DL. Effect of estrogen treatment on bone cortex of the young rat. Anat Rec. 1971;171(2):273-82.

11. Seifi M, Ashiri M, Hedayati M. Effect of sexual hormone elimination on the changes of craniofacial dimensions in rats. Journal of Dental School Shahid Beheshti University of Medical Sciences. 2008;25(4):365-72.

12. Marquez Hernandez RA, Ohtani J, Fujita T, Sunagawa $\mathrm{H}$, Kawata T, Kaku M, et al. Sex hormones receptors play a crucial role in the control of femoral and mandibular growth in newborn mice. Eur J Orthod. 2011;33(5):564-9.

13. Fushimi S, Wada N, Nohno T, Tomita M, Saijoh K, Sunami S, et al. 17beta-Estradiol inhibits chondrogenesis in the skull development of zebrafish embryos. Aquat Toxicol. 2009;95(4):292-8. 
14. Mizuno $Y$, Hosoi $T$, Inoue $S$, Ikegami A, Kaneki M, Akedo Y, et al. Immunocytochemical identification of androgen receptor in mouse osteoclast-like multinucleated cells. Calcif Tissue Int. 1994;54(4):325-6.

15. Bellido T, Jilka RL, Boyce BF, Girasole G, Broxmeyer $\mathrm{H}$, Dalrymple $S A$, et al. Regulation of interleukin-6, osteoclastogenesis, and bone mass by androgens. The role of the androgen receptor. J Clin Invest. 1995;95(6):2886-95.

16. Riggs $B L$, Melton $\amalg$, 3rd. Involutional osteoporosis. N Engl J Med. 1986;314(26):1676-86.

17. Turner AS, Alvis M, Myers W, Stevens ML, Lundy MW. Changes in bone mineral density and bone-specific alkaline phosphatase in ovariectomized ewes. Bone. 1995;17(4

Suppl):395S-402S.

18. Harris B, Lovett L, Smith J, Read G, Walker R, Newcombe R. Cardiff puerperal mood and hormone study. III. Postnatal depression at 5 to 6 weeks postpartum, and its hormonal correlates across the peripartum period. Br J Psychiatry. 1996;168(6):739-44.

19. Yamashiro T, TakanoYamamoto T. Influences of ovariectomy on experimental tooth movement in the rat. J Dent Res. 2001;80(9):1858-61.

20. Haruyama N, Igarashi K, Saeki S, Otsuka-Isoya M, Shinoda $\mathrm{H}$, Mitani H. Estrous-cycle- dependent variation in orthodontic tooth movement. J Dent Res. 2002;81(6):406-10.

21. Gennari L, Merlotti D, De Paola V, Calabro A, Becherini L, Martini G, et al. Estrogen receptor gene polymorphisms and the genetics of osteoporosis: a HuGE review. Am J Epidemiol.

2005;161(4):307-20.

22. Howe K, Clark MD, Torroja

$\mathrm{CF}$, Torrance J, Berthelot C, Muffato $\mathrm{M}$, et al. The zebrafish reference genome sequence and its relationship to the human genome. Nature. 2013;496(7446):498-503.

23. Waterston RH, LindbladToh K, Birney E, Rogers J, Abril JF, Agarwal $P$, et al. Initial sequencing and comparative analysis of the mouse genome. Nature. 2002;420(6915):520-62.

24. Lander ES, Linton LM, Birren B, Nusbaum C, Zody MC, Baldwin J, et al. Initial sequencing and analysis of the human genome. Nature. 2001;409(6822):860-921.

25. Gibbs RA, Weinstock GM, Metzker ML, Muzny DM, Sodergren EJ, Scherer S, et al. Genome sequence of the Brown Norway rat yields insights into mammalian evolution. Nature. 2004;428(6982):493-521. 